\title{
Kepuasan pemustaka Perpustakaan UIN Sunan Gunung Djati Bandung dan pengaruh word of mouth pemustaka
}

\author{
Nailah Hanum Hanany ${ }^{1}$ Eded Sudirman ${ }^{2}$ \\ 1,2Pusat Perpustakaan UIN Sunan Gunung Djati \\ Jl. A. H. Nasution 105 Cibiru, Bandung, Jawa Barat, Indonesia 40614 \\ E-mail: 1nailah.hanany@uinsgd.ac.id, 2eded.sudirman@uinsgd.ac.id
}

Received: October 2018; Accepted: June 2019; Published: June 2019

\begin{abstract}
Library activities that are directly felt by users are services, which are considered the spearhead of libraries. Guarantee and empathy aspects of the Servqual Model and effect of service aspects on the LibQual + TM model are all closely related to one of the factors, namely librarian language skills, both verbal and non-verbal. Moreover, users who have used these services can be effective promotional tools to affect other users through Word of Mouth (WOM) promotion. WOM in an Islamic perspective can mean 'da'wah', an invitation to do good. This study aimed to examine perceptions of satisfaction with the librarian language skills and their relationship with WOM among UIN Sunan Gunung Djati Library users. Librarian language skills are divided into two categories, namely verbal and non-verbal. Verbal aspects consist of vocal parameters, word selection, sentence structure, and convenience aspects to be understood. Non-verbal aspects include gesture parameters, body position, tone, and intonation. The research method used survey method with a total sample of 400 users. Determination of the number of samples was performed by Slovin method and selected by accidental sampling technique. Results showed, Consumer Satisfaction Index (CSI) for verbal communication was 3.325, and non-verbal communication was 3.253. Both were in the "moderate" satisfaction range on a scale of 5 . More than $22 \%$ of satisfied and very satisfied users stated that their satisfaction would continue with various WOM activities to invite others to visit the library. This shows the influence of satisfaction with WOM activities, although still on a small scale.
\end{abstract}

Keywords: Library user's satisfaction; Language skill; Verbal; Non-verbal; Word of mouth

\begin{abstract}
Abstrak
Kegiatan perpustakaan yang langsung dirasakan oleh pemakai adalah pelayanan, sehingga pelayanan dianggap ujung tombak perpustakaan. Aspek jaminan dan empati pada Model Servqual dan aspek affect of service pada model LibQual+TM, semuanya berkaitan erat dengan salah satu faktor yaitu kemampuan bahasa pustakawan, baik verbal maupun non verbal. Selain itu, pemustaka yang telah menggunakan jasa layanan tersebut dapat menjadi alat promosi efektif untuk memengaruhi pemustaka lain dengan promosi berupa Word of Mouth (WOM), atau pesan dari mulut ke mulut. WOM dalam perspektif Islam bisa bermakna dakwah, ajakan untuk berbuat baik. Penelitian ini bertujuan melihat persepsi kepuasan terhadap kemampuan bahasa pustakawan dan hubungannya dengan WOM di kalangan Pemustaka UIN Sunan Gunung Djati (SGD). Kemampuan bahasa pustakawan dibagi ke dalam dua kategori, yaitu verbal dan non verbal. Aspek verbal terdiri dari parameter vokal, pemilihan kata, struktur kalimat, dan aspek kemudahan untuk dipahami. Aspek non verbal terdiri dari parameter gestur, posisi tubuh, nada, dan intonasi. Adapun metode penelitian yang digunakan adalah metode survey dengan jumlah sample sebanyak 400 pemustaka. Penentuan jumlah sampel dilakukan dengan metode Slovin dan dipilih dengan teknik sampling aksidental. Hasil penelitian menunjukan bahwa Indeks Kepuasan Konsumen (IKK) untuk komunikasi verbal bernilai 3,325, dan IKK untuk komunikasi non verbal bernilai 3,253. Keduanya berada pada rentang kepuasan "sedang" dalam skala 5. Pemustaka yang menyatakan diri puas dan sangat puas, lebih dari $22 \%$ menyatakan bahwa kepuasannya akan berlanjut pada berbagai variasi aktivitas WOM untuk mengajak orang lain berkunjung ke perpustakaan. Hal ini menunjukkan ada pengaruh kepuasan terhadap aktivitas WOM, walaupun masih kecil skalanya.
\end{abstract}

Kata Kunci: Kepuasan pemustaka; Kemampuan bahasa; Verbal; Non verbal; Word of mouth 


\section{PENDAHULUAN}

Perpustakaan ialah lembaga informasi yang bersifat ilmiah dan berfungsi mengembangkan dunia pendidikan. Maka, perpustakaan pun memiliki program yang mengandung nilai dan unsur pembelajaran, penelitian, pembinaan, pengembangan, dan ilmu pengetahuan. Suwarno (2009) menyatakan bahwa,

“Berbagai kegiatan tersebut berorientasi pada pencerahan dan penambahan wawasan bagi penggunanya. Sebagai penyimpan khazanah budaya bangsa perpustakaan berusaha meningkatkan apresiasi dan minat kunjung pemustaka melalui proses penyediaan bahan bacaan."

Sesuai hal ini, perpustakaan mengalami era masyarakat informasi, dimana perpustakaan, "Telah dimanfaatkan sebagai salah satu pusat informasi, sumber ilmu pengetahuan, penelitian, rekreasi dan pelestarian khazanah ilmu pengetahuan" (Pebrianto, 2010). Dengan demikian, perpustakaan sebagai pengelola informasi dituntut memenuhi kebutuhan pemustaka secara mudah, cepat, dan tepat, dengan memperhatikan kebutuhan dan harapan pemustaka. "Maka perpustakaan selalu berupaya untuk mengerti kebutuhan dan harapan pemustaka dalam memberikan layanan. Berbagai parameter layanan harus dapat diukur kinerjanya" (Kassim, 2009).

Soeatminah (1992) pun memberikan pendapat kalau,

“Kegiatan perpustakaan yang

langsung dirasakan oleh pemakai adalah pelayanan, karena pelayanan dianggap ujung tombak perpustakaan. Pada bagian pelayanan ini berlangsung hubungan antara pengguna dan penyedia jasa.
Salah satunya, ialah pelayanan sirkulasi sebagai kegiatan operasional perpustakaan dalam hal peminjaman buku dan bahan lainnya. Oleh karena itu, kinerja staf bagian sirkulasi sangat berpengaruh terhadap citra perpustakaan itu sendiri."

Pustakawan berkomunikasi langsung dengan pemustaka melalui pelayanan sirkulasi. Dengan demikian, pustakawan pun dituntut melayani pemustaka secara profesional. Pelayanan yang baik dari pustakawan akan berpengaruh pada kepuasan pemustaka. Model kualitas pelayanan yang populer adalah model servqual (service quality) yang dikembangkan Parasuraman, Zeithmal, and Berry (1988) dalam Fatmawati (2013), yang menyatakan bahwa kualitas layanan Servqual menggunakan parameter di antaranya, "(1) Kehandalan, (2) jaminan, (3) daya tanggap, (4) empati, dan (5) bukti langsung." Metode Servqual pernah juga digunakan untuk mengevaluasi kualitas layanan perpustakaan akademik (Brendan, \& Asogwa, 2014). Metode lain untuk mengukur kepuasan adalah metode LibQual+TM, yang mendasarkan kualitas pada 4 dimensi, yaitu "Sikap petugas perpustakaan dalam melayani pemustaka (service affect), fasilitas dan suasana ruang perpustakaan (library as Place), petunjuk dan sarana akses (personal control), dan akses informasi (information access)" (Fatmawati, 2013).

Aspek jaminan dan empati pada model Servqual dan aspek affect of service pada model LibQual+TM, semuanya berkaitan erat dengan salah satu faktor yaitu kemampuan bahasa, baik kemampuan bahasa lisan dan tulisan. Hal ini berkaitan dengan kepuasan pelanggan (Fatmawati, 2012). 
Indrawati (2012) menyebutkan aspek kemampuan bahasa lisan berkaitan juga dengan masalah, "Gerak tubuh, intonasi, vokal dan tata kalimat yang baik." Selain itu, “Bahasa lisan dan tulisan sebagai sarana komunikasi efektif berkaitan dengan kepuasan pelanggan" (Yanti, 2013).

Kepuasan pelanggan, dalam hal ini adalah pemustaka yang berkaitan dengan aspek promosi yang salah satunya melalui Word of Mouth (WOM). WOM adalah kegiatan mengirimkan informasi dari satu orang kepada orang lain mengenai suatu hal atau pun suatu produk, memberikan rekomendasi memberikan komentar mengenai produk dan pengetahuan tertentu (Li \& Du, 2011). Brown, Barry, Dacin, and Gunst (2005) menyatakan bahwa, "WOM terjadi ketika pelanggan berbicara kepada orang lain mengenai pendapatnya tentang suatu merek, produk, layanan."

Bahkan Martin and Lueg (2013), berpendapat kalau WOM dapat memengaruhi seseorang dalam mengambil sebuah keputusan. Pengaruh WOM lebih besar seiring meningkatnya sarana komunikasi yang didukung teknologi, seperti media sosial (Chen, Wang, \& Xie, 2011). Berhubungan dengan konteks layanan perpustakaan, kepuasan pemustaka tentunya akan menarik pemustaka lain untuk datang atas informasi melalui WOM ini.

Putri and Suhariadi (2013) pun berpendapat bahwa,

"Pemustaka yang telah menggunakan jasa layanan tersebut dapat menjadi alat promosi efektif untuk memengaruhi mahasiswa lain. Banyak studi yang menyatakan bahwa promosi berupa WOM yang positif akan memengaruhi minat seseorang untuk melakukan aktivitas atau tindakan yang langsung terlibat dalam mendapatkan, mengonsumsi dan menghabiskan produk dan jasa. Kepuasan pelanggan dapat memberikan banyak manfaat bagi perusahaan, pelanggan yang sangat puas akan menyebarkan cerita positif dari mulut ke mulut (WOM) dan malah akan menjadi iklan berjalan."

WOM yang positif dapat bertindak sebagai agen penjualan yang handal dan sangat dipercaya, namun sebaliknya bila WOM yang negatif dapat sangat merugikan suatu produk layanan, termasuk layanan perpustakaan. Berger (2014) mengatakan bahwa, WOM adalah suatu komentar positif atau negatif tentang suatu jasa yang disebarkan seseorang kepada orang lain. Bahkan WOM berdampak penting pada perilaku pelanggan. WOM yang memberikan dampak positif dalam perspektif Islam bisa bermakna dakwah, ajakan untuk berbuat baik.

Fenomena WOM bisa dimanfaatkan dalam menarik minat pemustaka terhadap layanan perpustakaan. Salah satu hal yang perlu dilihat adalah kepuasan pemustaka terhadap kemampuan bahasa pustakawan. Hal ini mengingat kepuasan terhadap kualitas layanan perpustakaan sangat dipengaruhi kemampuan pustakawan dalam berkomunikasi.

Penelitian ini membahas mengenai persepsi kepuasan terhadap kemampuan bahasa pustakawan dan hubungannya dengan WOM di kalangan Pemustaka UIN Sunan Gunung Djati (SGD) Bandung. Kemampuan bahasa akan ditinjau dari sisi lisan dan tulisan. Kemampuan bahasa lisan akan dilihat dari persepsi pemustaka terhadap kemampuan komunikasi lisan pustakawan. Sementara kemampuan bahasa tulisan akan dilihat dari tulisan resume buku yang dibuat oleh pustakawan, 
baik buku asing maupun buku berbahasa Indonesia.

Setiap unit kerja perpustakaan tentu memiliki keahlian (skill) yang berbeda pada Sumber Daya Manusia (SDM) atau pustakawan. Pemilihan tempat di Pusat Perpustakaan UIN SGD Bandung, merupakan hal baru dalam penelitian ini. Perpustakaan UIN SGD Bandung, selain mengemban fungsi layanan perpustakaan, juga memiliki misi dakwah sesuai dengan misi perguruan tinggi. Pengukuran kepuasan pemustaka terhadap bahasa pustakawan dan dampaknya terhadap ajakan kepada pemustaka lain untuk berkunjung ke perpustakaan akan menjadi masukan yang berarti bagi pihak UIN SGD Bandung.

\section{METODE PENELITIAN}

Penelitian ini merupakan penelitian kuantitatif menggunakan metode survey. Subjek penelitian adalah pemustaka di Pusat Perpustakaan UIN SGD Bandung. Jumlah populasi penelitian ini sebanyak 20.000 orang, yang merupakan anggota perpustakaan aktif. Anggota aktif yang dimaksud merupakan mahasiswa aktif, staf, dosen dan anggota umum yang melakukan transaksi minimal 1 kali dalam setahun.

Jumlah sample ditentukan dengan Metode Slovin yang ditentukan dengan persamaan:

$$
n=\frac{N}{1+N\left(d^{2}\right)}
$$

Di mana:

$\mathrm{n}$ = Jumlah sampel

$\mathrm{N}=$ Jumlah populasi

$\mathrm{d}=$ Tingkat kesalahan yang diinginkan

Berdasarkan tingkat kesalahan sebesar 5\%, didapatkan jumlah sampel sebanyak 392 orang (dibulatkan $\approx 400$ orang). Pemilihan responden dilakukan dengan menggunakan teknik sampling aksidental.

Sesuai gambar 1, menunjukan diagram variabel dan kerangka berpikir penelitian.

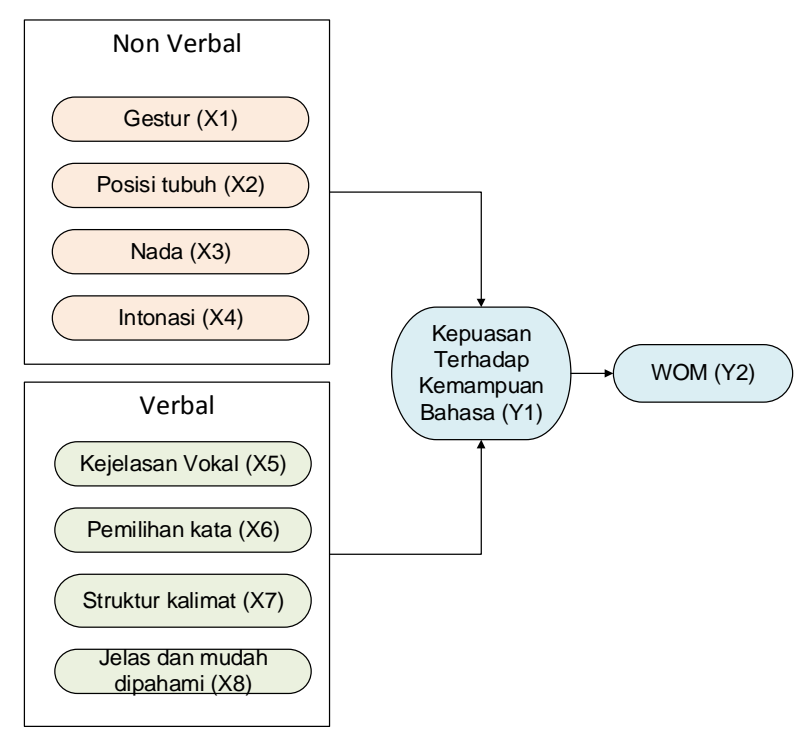

Gambar 1. Variabel dan kerangka hubungan antar variabel

Sumber: Analisis penelitian, 2018

Objek penelitian mencakup 2 hal yaitu, kemampuan bahasa verbal dan non verbal pustakawan di Pusat Perpustakaan UIN SGD Bandung Bandung. Instrumen penelitian menggunakan kuesioner dengan membagi dua kelompok parameter kemampuan bahasa pustakawan, yaitu aspek verbal, dan non verbal yang masingmasing terdiri dari 4 parameter. Aspek verbal terdiri dari parameter vokal, pemilihan kata, struktur kalimat, dan aspek kemudahan memahami. Aspek non verbal terdiri dari parameter gestur, posisi tubuh, nada, dan intonasi. Penilaian kepuasan dilakukan dalam skala 5 (sangat tidak puas, tidak puas, sedang, puas, dan sangat puas). Selain kepuasan, pada penelitian ini juga dinilai harapan/tingkat kepentingan terhadap aspek dan parameter yang sama. Analisis menggunakan diagram radar yang 
dilakukan untuk melihat perbedaan antara kepuasan dan harapan pada setiap parameter.

Selanjutnya hasil survey kepuasan tersebut dikaitkan terhadap aspek WOM dengan 4 variasi kegiatan yang mungkin dilakukan pemustaka. Untuk melihat kinerja pada masing-masing variabel, dilakukan gap analysis antara kepuasan dan harapan. Analisis hubungan antara kepuasan dengan WOM dilakukan dengan pendekatan statistik melalui summary model untuk melihat nilai korelasi (R) antara dua variabel. Selain itu, analisis menggunakan juga perhitungan regresi linear untuk melihat model hubungan antar variabel dan seberapa kuat hubungan tersebut. Akhir pembahasan, untuk mempertegas aspek mana yang harus diprioritaskan dalam perbaikan kemampuan bahasa pustakawan telah dilakukan menggunakan Importance Performance Analysis (IPA).

\section{HASIL DAN PEMBAHASAN}

Berdasarkan data, segmentasi pengguna dapat dibedakan dari sisi jenis kelamin dan status responden (pekerjaan). Jika dilihat berdasarkan jenis kelamin, dari 400 orang responden, sebanyak 240 orang berjenis kelamin perempuan dan 160 orang laki-laki, sebagaimana ditunjukan pada tabel 1.

Tabel 1

Jumlah responden berdasarkan jenis kelamin

\begin{tabular}{lll}
\hline Jenis kelamin & Jumlah & Persentase \\
\hline Laki-laki & 160 & $40 \%$ \\
Perempuan & 240 & $60 \%$ \\
Jumlah & 400 & $100 \%$ \\
\hline
\end{tabular}

Berdasarkan statusnya, dari 400 orang responden, sebanyak 399 orang mahasiswa, dan 1 orang dari kalangan umum, sebagaimana ditunjukkan pada tabel 2 .
Tabel 2

Jumlah responden berdasarkan status

\begin{tabular}{lll}
\hline Status & Jumlah & Persentase \\
\hline Mahasiswa & 399 & $99,70 \%$ \\
Dosen/Pegawai UIN & 0 & $0 \%$ \\
Umum & 1 & $0,30 \%$ \\
Jumlah & 400 & $100 \%$ \\
\hline
\end{tabular}

Sesuai aspek tingkat kunjungan, berdasarkan hasil survei, dari 400 responden, mayoritas pernah berkunjung ke perpustakaan tetapi tidak rutin. Jumlah responden berdasarkan tingkat kunjungannya dapat dilihat pada tabel 3.

Tabel 3

Jumlah responden berdasarkan kunjungan dalam satu pekan

\begin{tabular}{lll}
\hline $\begin{array}{l}\text { Kunjungan dalam satu } \\
\text { pekan }\end{array}$ & Jumlah & Persentase \\
\hline Setiap hari & 22 & $5.50 \%$ \\
Antara 2-3 kali & 145 & $36.25 \%$ \\
sekali & 56 & $14 \%$ \\
Pernah, tapi tidak rutin & 177 & $44.25 \%$ \\
Jumlah & 400 & $100 \%$ \\
\hline
\end{tabular}

Berdasarkan hasil survei, kepuasan responden terhadap komunikasi verbal pustakawan, menunjukan angka masih rendah, yaitu dibawah 50\%. Maka, dalam pengelolaan ini yang termasuk puas adalah responden yang memilih "puas" (4) dan "sangat puas" (5). Sementara itu, responden yang dianggap tidak puas adalah responden yang memilih "tidak puas" (2) dan "sangat tidak puas" (1).

Kepuasan ini bervariasi apabila dilihat dari tiap atribut pertanyaan. Pada tabel 4, sesuai aspek verbal, responden paling banyak merasa puas untuk atribut B1.3, "Kalimat yang disampaikan jelas dan mudah dipahami persyaratan", yaitu $45 \%$, artinya ada 180 responden yang menyatakan "puas" atau "sangat puas", dengan skor rata-rata 3,41. Sementara yang paling rendah adalah B1.2, "Pustakawan menggunakan pilihan kata yang baik dan tepat dalam berkomunikasi", dengan skor 
rata-rata 3,26. Sementara itu, dalam aspek non verbal, tingkat kepuasan/kinerja memiliki nilai rata-rata tertinggi sebesar 3,30 untuk atribut B2.4, "pustakawan menggunakan intonasi yang tepat dalam berkomunikasi', dan memiliki tingkat kepuasan/kinerja terendah sebesar 3,18 untuk atribut B2.1 yaitu "gestur pustakawan membuat nyaman pemustaka dan mendukung komunikasi verbal".

Pada tabel 5 menunjukan nilai untuk tingkat kepentingan/harapan dari responden pemustaka terhadap komunikasi berbahasa pustakawan. Berdasarkan tabel 5, dapat dilihat bahwa tingkat kepentingan/harapan aspek verbal memiliki nilai tertinggi sebesar 4,16 untuk atribut B1.2 yaitu "pustakawan menggunakan pilihan kata yang baik dan tepat dalam berkomunikasi", dan memiliki tingkat kepentingan terendah sebesar 4,09 untuk atribut B1.1 yaitu "vokal yang diucapkan pustakawan cukup jelas." Jadi, dari aspek verbal pustakawan memiliki kemampuan yang tinggi dalam menggunakan kata yang baik dan tepat dalam berkomunikasi dengan pemustaka.

Sedangkan untuk aspek non verbal, tingkat kepentingan/harapan untuk bahasa non verbal memiliki nilai tertinggi sebesar 4,17 untuk atribut B2.4 yaitu "pustakawan menggunakan intonasi yang tepat dalam berkomunikasi", dan memiliki tingkat kepentingan/harapan terendah sebesar 4,07 untuk atribut B2.1 yaitu "gestur pustakawan membuat nyaman pemustaka dan mendukung komunikasi verbal. Jadi, dari aspek non verbal pustakawan telah menggunakan intonasi yang tepat dalam berkomunikasi dengan pemustaka.
Tabel 4

Tingkat harapan terhadap kemampuan berbahasa pustakawan

\begin{tabular}{|c|c|c|}
\hline Kode & Hal yang dinilai & $\begin{array}{l}\text { Rata-rata } \\
\text { Harapan }\end{array}$ \\
\hline \multicolumn{3}{|c|}{ Aspek verbal } \\
\hline B1.1 & $\begin{array}{l}\text { Vokal yang diucapkan } \\
\text { pustakawan cukup jelas }\end{array}$ & $4.09 *$ \\
\hline B1.2 & $\begin{array}{l}\text { Pustakawan } \\
\text { menggunakan pilihan } \\
\text { kata yang baik dan tepat } \\
\text { dalam berkomunikasi }\end{array}$ & $4.16^{*}$ \\
\hline B1.3 & $\begin{array}{l}\text { Kalimat yang } \\
\text { disampaikan jelas dan } \\
\text { mudah dipahami }\end{array}$ & 4.15 \\
\hline B1.4 & $\begin{array}{l}\text { Struktur kalimat } \\
\text { pustakawan dalam } \\
\text { berkomunikasi cukup } \\
\text { baik }\end{array}$ & 4.14 \\
\hline Aspek & non verbal & \\
\hline B2.1 & $\begin{array}{l}\text { Gestur pustakawan } \\
\text { membuat nyaman } \\
\text { pemustaka dan } \\
\text { mendukung komunikasi } \\
\text { verbalnya }\end{array}$ & 4.07 \\
\hline B2.2 & $\begin{array}{l}\text { Posisi tubuh pustakawan } \\
\text { saat melakukan } \\
\text { komunikasi dengan } \\
\text { pemustaka tepat dan } \\
\text { nyaman untuk } \\
\text { berkomunikasi }\end{array}$ & 4.12 \\
\hline B2.3 & $\begin{array}{l}\text { Nada bicara pustakawan } \\
\text { dalam berkomunikasi } \\
\text { dengan pemustaka cukup } \\
\text { memadai untuk dapat } \\
\text { didengar }\end{array}$ & 4.14 \\
\hline B2.4 & $\begin{array}{l}\text { Pustakawan } \\
\text { menggunakan intonasi } \\
\text { yang tepat dalam } \\
\text { berkomunikasi }\end{array}$ & 4.17 \\
\hline
\end{tabular}

Selanjutnya, dapat terlihat perbedaan antara kepuasan dan harapan pada aspek komunikasi verbal terkait kepuasan pemustaka terhadap pustakawan yang dapat dilihat pada diagram radar gambar 2 . 


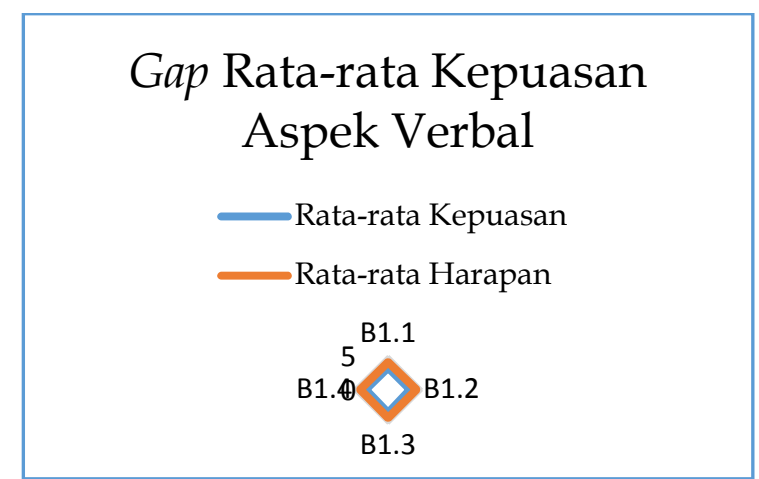

Gambar 2. Radar diagram kepuasan dan harapan komunikasi verbal

Sumber: Analisis penelitian, 2018

Sementara perbedaan antara kepuasan dan harapan pada aspek komunikasi non verbal dapat dilihat pada diagram radar gambar 3.

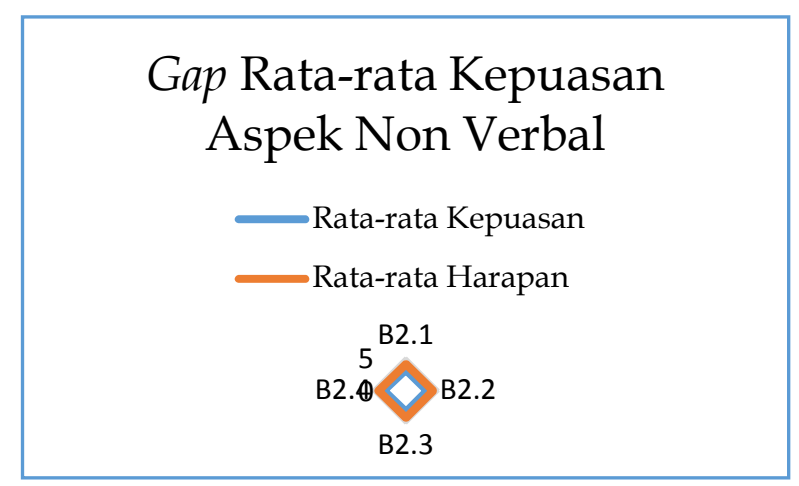

Gambar 3. Radar diagram gap kepuasan dan harapan komunikasi non verbal

Sumber: Analisis penelitian, 2018

Perbedaan (gap) tertinggi antara kepentingan dan kepuasan aspek non verbal adalah atribut B2.1, yaitu "Gestur pustakawan membuat nyaman pemustaka dan mendukung komunikasi verbal", sebesar 0,89 dan gap terkecil adalah atribut B2.2 yaitu "Posisi tubuh pustakawan saat melakukan komunikasi dengan pemustaka tepat dan nyaman untuk berkomunikasi"

Kinerja setiap atribut ditetapkan dengan menentukan interval terlebih dahulu. Rumus yang dipakai adalah :

$$
R \quad=\frac{I}{\sum K}
$$

Pada kasus ini, Range Consumer Satisfaction Index (CSI)/Indeks Kepuasan Konsumens
$(\mathrm{IKK})$ adalah $=(5-1) / 5=0,8$. Jadi, batasbatas nilai IKK mengacu pada tabel 6 .

Tabel 5

Range indeks kepuasan

\begin{tabular}{lll}
\hline $\begin{array}{l}\text { Index CSI } \\
\text { (IKK) }\end{array}$ & $\begin{array}{l}\text { Konversi } \\
\text { IKK }\end{array}$ & $\begin{array}{l}\text { Kinerja } \\
\text { parameter }\end{array}$ \\
\hline$>4,2-5,00$ & $84,01-100$ & Sangat puas \\
$>3,40-4,2$ & $68,01-84,00$ & Puas \\
$>2,6-3,4$ & $51,01-68,00$ & Sedang \\
$>1,8-2,6$ & $36,01-51,00$ & Tidak puas \\
$1,00-1,8$ & $20,00-36,00$ & Sangat tidak \\
& & puas \\
\hline
\end{tabular}

Perhitungan IKK dengan mempertimbangkan, "nilai Weighting Factor (WF), yaitu nilai rata-rata kepentingan dalam angka persentase dari total rata-rata tingkat kepentingan seluruh atribut yang diuji, dan Weight Score (WS), yaitu perkalian antara nilai rata-rata tingkat kinerja/kepuasan masing-masing atribut dengan WF masing-masing atribut" (Farida, 2011). Berdasarkan perhitungan, diperoleh tabel IKK untuk aspek Verbal pada tabel 7.

Sesuai standar rentang IKK yang dibahas pada tabel 6, maka komunikasi aspek verbal dengan skala IKK sebesar 3,325 berada pada kinerja sedang/biasa saja. Sementara untuk aspek non verbal, diperoleh tabel perhitungan IKK pada tabel 16.

Sesuai standar rentang CSI yang dibahas pada tabel 6, maka komunikasi aspek non verbal dengan skala IKK sebesar 3,253 berada pada kinerja sedang/biasa saja. Sementara itu, penilaian 4 aspek yang berkaitan dengan WOM dilakukan dengan skala 5, mulai dari sangat tidak sesuai, bernilai 1, sampai sangat sesuai, bernilai 5 . Keempat aspek tersebut berada di tabel 15, yang paling banyak dipilih oleh responden sebagai tanda setuju adalah butir C4, "apakah Anda akan mempromosikan kualitas layanan, khususnya aspek 
komunikasi pustakawan kepada orang lain, agar orang lain berkunjung ke perpustakaan?", yang dipilih oleh 150 responden. Termasuk ke dalam 150 orang ini adalah responden yang memilih 4 dan 5 .

Hal ini menunjukan bahwa sebanyak 150 responden, atau 37,5\% responden setuju atau sangat setuju dengan pernyataan butir $\mathrm{C} 4$ tersebut. Jika ditinjau secara umum, dari butir C1 sampai C4, maka di atas $22 \%$ responden akan berkontribusi terhadap aspek WOM dalam berbagai variasinya.

Sementara itu, rata-rata nilai WOM sebesar 2,85 untuk semua atribut. Rata-rata tertinggi sebesar 3,07 dimiliki oleh atribut C4, dan rata-rata terendah sebesar 2,69 dimiliki atribut C2. Dilihat dari data ini, kepuasan terhadap komunikasi pustakawan berpengaruh terhadap WOM walaupun pengaruhnya masih kecil.

Hubungan kepuasan komunikasi aspek verbal dari pustakawan terhadap WOM dapat digambarkan tabel hubungan yang ditunjukan pada tabel 10.

\section{Tabel 6}

Hubungan tingkat kepuasan responden berdasarkan aspek verbal terhadap WOM

\begin{tabular}{lcccc}
\hline & C1 & C2 & C3 & C4 \\
\hline $\begin{array}{l}\text { Vokal yang diucapkan } \\
\text { pustakawan cukup jelas }\end{array}$ & 3.28 & 3.28 & 3.28 & 3.28 \\
$\begin{array}{l}\text { Pustakawan } \\
\text { menggunakan pilihan } \\
\text { kata yang baik dan } \\
\text { tepat dalam } \\
\text { berkomunikasi }\end{array}$ & 3.26 & 3.26 & 3.26 & 3.26 \\
$\begin{array}{l}\text { Kalimat yang } \\
\text { disampaikan jelas dan } \\
\text { mudah dipahami }\end{array}$ & 3.41 & 3.41 & 3.41 & 3.41 \\
$\begin{array}{l}\text { Struktur kalimat } \\
\text { pustakawan dalam } \\
\text { berkomunikasi cukup } \\
\text { baik }\end{array}$ & 3.35 & 3.35 & 3.35 & 3.35 \\
\hline
\end{tabular}

Sesuai tabel 10, contoh rata-rata tingkat kepuasan responden dilihat dari atribut B1.1, "vokal yang diucapkan pustakawan cukup jelas", memengaruhi responden untuk sering berdiskusi dengan teman/pihak lain terkait kualitas layanan pustakawan UIN SGD Bandung (C1) sebesar 3,28. Sesuai atribut kepuasan komunikasi verbal, atribut B1.3 yang paing berpengaruh ke WOM dengan nilai ratarata 3,41 .

Sementara itu, hubungan kepuasan komunikasi aspek non verbal dari pustakawan terhadap WOM dapat digambarkan dengan tabel hubungan yang ditunjukan pada tabel 12 dan tabel 14 . Sebagai contoh, rata-rata tingkat kepuasan responden dilihat dari atribut B2.4, "Pustakawan menggunakan intonasi yang tepat dalam berkomunikasi", memengaruhi responden untuk sering berdiskusi dengan teman/pihak lain terkait kualitas layanan pustakawan UIN SGD Bandung (C1) sebesar 3,30.

Pada bagian ini juga akan dilihat hubungan antara kepuasan pemustaka terhadap komunikasi pustakawan (verbal/non verbal) terhadap WOM, yang dicari relasinya adalah pemustaka yang merasa Puas (memilih 4) atau Merasa Sangat Puas (memilih 5), terhadap WOM. Tabel 12 berikut menunjukan ringkasan hubungan kepuasan komunikasi aspek verbal dengan WOM.

Tabel 7

Summary model hubungan kepuasan aspek verbal dengan WOM

\begin{tabular}{lllll}
\hline Model R & $\begin{array}{l}\mathbf{R} \\
\text { Square }\end{array}$ & $\begin{array}{l}\text { Adjusted } \\
\mathbf{R} \\
\text { square }\end{array}$ & $\begin{array}{l}\text { Std. error of } \\
\text { the estimate }\end{array}$ \\
\hline 1 & $\begin{array}{c}.94 \\
8 \mathrm{a}\end{array}$ & & .898 & 11.770 \\
\hline
\end{tabular}

a. Predictors: (Constant), Kepuasan 
Tabel di atas menunjukan bahwa nilai korelasi/hubungan ( $\mathrm{R}$ ) sebesar 0,948 dan presentase pengaruh kepuasan terhadap WOM sebesar 89,8 \%.

Tabel 8

Anova untuk aspek Verbal

ANOVAa

\begin{tabular}{|c|c|c|c|c|c|}
\hline Model & $\begin{array}{l}\text { Sum of } \\
\text { Squares }\end{array}$ & Df & $\begin{array}{l}\text { Mean } \\
\text { Square }\end{array}$ & $\mathbf{F}$ & Sig. \\
\hline $\begin{array}{l}1 \text { Regressio } \\
\mathrm{n}\end{array}$ & 2439.914 & 1 & 2439.914 & $\begin{array}{l}17.6 \\
11\end{array}$ & $.052^{\mathrm{b}}$ \\
\hline Residual & 277.086 & 2 & 138.543 & & \\
\hline Total & 2717.000 & 3 & & & \\
\hline
\end{tabular}

a. Dependent Variable: WOM

b. Predictors: (Constant), Kepuasan

Tabel 8 menunjukan adanya pengaruh kepuasan terhadap WOM. Pada Tabel 8 diperoleh $\mathrm{F}$ hitung sebesar 17,611 dengan tingkat signifikasi sebesar 0,052. Tingkat signifikasi dikatakan linear jika nilai signifikasi < 0,05. Berdasarkan data yang ada, maka dapat dilihat bahwa hubungannya terhadap aktivitas WOM tidak linear.

Tabel 9

Coefficients aspek verbal

\begin{tabular}{|c|c|c|c|c|}
\hline \multicolumn{5}{|c|}{ Coefficients ${ }^{a}$} \\
\hline \multirow[b]{2}{*}{ Model } & $\begin{array}{l}\text { Unstand } \\
\text { Coefficie }\end{array}$ & $\begin{array}{l}\text { ardized } \\
\text { ents }\end{array}$ & $\begin{array}{l}\text { Standardi } \\
\text { zed } \\
\text { Coefficie } \\
\text { nts }\end{array}$ & \multirow[b]{2}{*}{ Sig. } \\
\hline & B & $\begin{array}{l}\text { Std. } \\
\text { Error }\end{array}$ & Beta & \\
\hline $\begin{array}{ll}1 & \text { (Cons } \\
& \tan t)\end{array}$ & -272.095 & 93.023 & & -2.925 .100 \\
\hline $\begin{array}{l}\text { Kepu } \\
\text { asan }\end{array}$ & 2.326 & .554 & .948 & $\begin{array}{ll}4.197 & .052\end{array}$ \\
\hline
\end{tabular}

a. Dependent Variable: WOM

Berikut ringkasan hubungan kepuasan non verbal dengan WOM.

Tabel 10

Summary model hubungan kepuasan aspek nonverbal dengan WOM

\begin{tabular}{|c|c|c|c|c|}
\hline \multicolumn{5}{|c|}{ Model Summary } \\
\hline $\begin{array}{l}\text { Mod } \\
\text { el }\end{array}$ & $\mathbf{R}$ & R Square & $\begin{array}{l}\text { Adjusted R } \\
\text { square }\end{array}$ & $\begin{array}{l}\text { Std. error of } \\
\text { the estimate }\end{array}$ \\
\hline 1 & $.789^{a}$ & .623 & .435 & 22.629 \\
\hline
\end{tabular}

Predictors: (Constant), Kepuasan
Sesuai tabel 10 menunjukan bahwa nilai korelasi/hubungan ( $R$ ) sebesar 0,789 dan presentase pengaruh kepuasan terhadap WOM sebesar 62,3 \%

Tabel 11

Anova untuk aspek non verbal

ANOVAa

\begin{tabular}{|c|c|c|c|c|c|c|}
\hline \multicolumn{2}{|c|}{ Model } & \multicolumn{2}{|c|}{$\begin{array}{l}\text { Sum of } \\
\text { Squares df }\end{array}$} & $\begin{array}{l}\text { Mean } \\
\text { Square }\end{array}$ & & Sig. \\
\hline 1 & $\begin{array}{l}\text { Regress } \\
\text { ion }\end{array}$ & 1692.882 & 1 & $\begin{array}{l}1692.88 \\
2\end{array}$ & 3.306 & $.211^{\mathrm{b}}$ \\
\hline & $\begin{array}{l}\text { Residua } \\
1\end{array}$ & 1024.118 & 2 & 512.059 & & \\
\hline & Total & 2717.000 & 3 & & & \\
\hline
\end{tabular}

a. Dependent Variable: WOM

b. Predictors: (Constant), Kepuasan

Pada tabel Anova di atas menunjukan pengaruh kepuasan terhadap WOM. Pada tabel diperoleh F hitung sebesar 3,306 dengan tingkat signifikasi sebesar 0,211. Tingkat signifikasi dikatakan linear jika nilai signifikasi < 0,05. Hasil di atas menunjukan tingkat signifikasinya sebesar 0,211, yang artinya bahwa walaupun berhubungan, namun hubungannya tidak bisa didekati dengan model linear.

Pada tahap akhir, dilakukan analisis Importance Performance Analysis (IPA) untuk lebih menegaskan aspek yang perlu diprioritaskan dalam perbaikan kemampuan pustakawan. Analisa IPA dilakukan sebagai analisa strategi untuk meningkatkan kepuasan pelanggan. Proses diawali dengan menghitung rata-rata dan menentukan sumbu $\mathrm{X}$ dan $\mathrm{Y}$. Perhitungan IPA dilakukan dengan persamaan:

$$
\overline{\bar{x}}=\frac{\sum_{l=1}^{n} \overline{x_{l}}}{k} \text { dan } \overline{\bar{y}}=\frac{\sum_{l=1}^{n} \overline{y_{l}}}{k}
$$

nilai $\overline{\bar{x}}$ adalah skor rata-rata dari total ratarata bobot tingkat kinerja dari seluruh atribut yang memengaruhi kepuasan pelanggan, $\bar{y}$ adalah skor rata-rata dari total 
rata-rata bobot tingkat kepentingan seluruh atribut yang memengaruhi kepuasan pelanggan, dan $k$ adalah banyaknya atribut yang memengaruhi kepuasan pelanggan. Selanjutnya $\overline{\bar{x}}$ dijadikan sebagai sumbu vertikal dan $\overline{\bar{y}}$ dijadikan sebagai sumbu horisontal dalam diagram kartesius IPA. Pengukuran IPA dijabarkan ke dalam diagram Kartesian. IPA untuk aspek verbal dapat dilihat pada gambar 4 .



Gambar 4. IPA aspek verbal Sumber: Analisis penelitian, 2018

Farida (2011) menjelaskan,

"Kuadran pertama terletak di sebelah kiri atas, kuadran kedua berada di sebelah kanan atas, kuadran ketiga berada di sebelah kiri bawah, dan kuadran keempat berada di sebelah kanan bawah. Posisi masing-masing atribut pada keempat kuadran tersebut dijadikan sebagai landasan strategi untuk meningkatkan kepuasan konsumen perpustakaan terhadap komunikasi pustakawan."

Sementara itu, IPA aspek non verbal dapat dilihat pada gambar 5 menunjukkan posisi masing-masing atribut yang mempengaruhi kepuasan pemustaka terhadap pustakawan yang ada di Pusat Perpustakaan UIN SGD Bandung berdasarkan kuadran IPA.

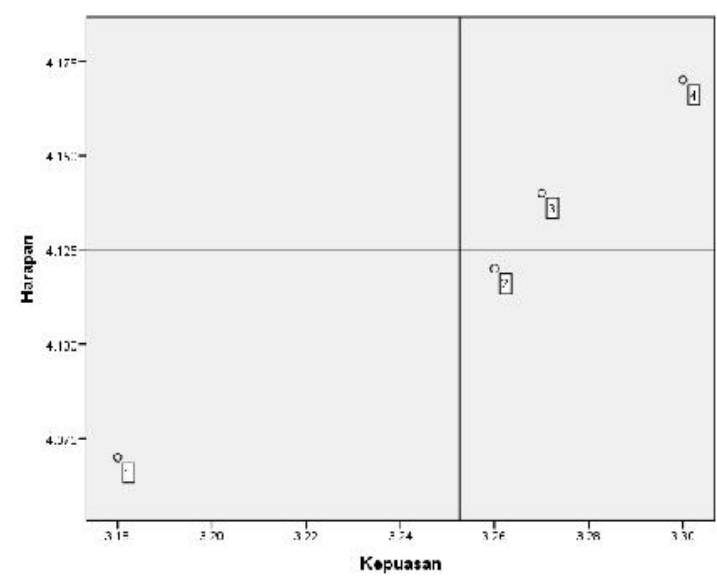

Gambar 5. IPA aspek non verbal Sumber: Analisis penelitian, 2018

Sesuai gambar 4 dan 5, menunjukkan posisi masing-masing atribut yang memengaruhi kepuasan konsumen perpustakaan terhadap bahasa pustakawan dalam kuadrannya masing-masing. Interpretasi dari IPA dapat dilihat pada keempat kuadaran.

"Kuadran pertama (prioritas utama). Atribut yang berada dalam kuadran ini harus lebih diprioritaskan dan diperbaiki, sehingga kinerjanya meningkat dan menjadi lebih baik lagi. Hal ini disebabkan atribut-atribut ini memiliki nilai kepentingan yang tinggi bagi konsumen, namun kinerjanya masih kurang memuaskan" (Farida, 2011). Atribut verbal yang berada pada kuadran ini adalah aribut B1.2 (pustakawan menggunakan pilihan kata yang baik dan tepat dalam berkomunikasi). Sementara untuk aspek non verbal tidak ada atribut yang berada pada kuadran ini.

Kuadran kedua (pertahankan prestasi), terdapat faktor-faktor yang dianggap penting dan diharapkan sementara saat ini responden pengguna layanan perpustakaan sudah merasa puas. Pustakawan wajib untuk mempertahankan prestasi kinerja tersebut. Atribut aspek verbal yang berada pada kuadran ini adalah B1.3 (kalimat yang disampaikan jelas 
dan mudah dipahami) dan B1.4 (struktur kalimat pustakawan dalam berkomunikasi cukup baik). Untuk aspek poin verbal, atribut yang berada pada kuadran ini adalah B2.3 (nada bicara pustakawan dalam berkomunikasi dengan pemustaka cukup memadai untuk dapat didengar) dan B2.4 (pustakawan menggunakan intonasi yang tepat dalam berkomunikasi).

Kuadaran ketiga ialah prioritas rendah (low priority). Pada kuadaran ini terdapat, "Faktor-faktor yang dianggap mempunyai tingkat persepsi atau kinerja aktual yang rendah dan dianggap tidak terlalu penting" (Andinouval R., 2018), dan atau tidak terlalu diharapkan oleh pengguna layanan sehingga Perpustakaan dan pustakawan tidak perlu memprioritaskan atau memberikan perhatian lebih pada faktor-faktor tersebut. Atribut yang berada pada kuadran ini adalah B1.1 (vokal yang diucapkan pustakawan cukup jelas). Untuk aspek non verbal, atribut yang berada pada kuadran ini adalah B2.1 (gestur pustakawan membuat nyaman pemustaka dan mendukung komunikasi verbal).

Kuadran keempat, disebut "Berlebihan (possibly overkill). Pada kuadaran ini terdapat faktor-faktor yang dianggap tidak terlalu penting dan tidak terlalu diharapkan oleh pengguna layanan sementara pengguna layanan sudah merasa puas" (Andinouval R., 2018). Maka, perpustakaan/pustakawan lebih baik mengalokasikan, "Sumber daya yang terkait pada faktor tersebut kepada faktor lain yang lebih memiliki tingkat prioritas lebih tinggi" (Siyamto, 2017). Tidak ada atribut komunikasi verbal yang masuk dalam kuadran ini. Sementara itu, untuk aspek non verbal, atribut yang berada pada kuadran ini adalah B2.2 (posisi tubuh pustakawan saat melakukan komunikasi dengan pemustaka tepat dan nyaman untuk berkomunikasi).

\section{SIMPULAN}

Berdasarkan pembahasan di atas, terlihat bahwa nilai IKK untuk komunikasi verbal termasuk berkinerja SEDANG. Jika dibandingkan antara rata-rata kepuasan dan harapan, masih ada kesenjangan yang perlu diperkecil agar kualitas layanan dalam hal komunikasi pustakawan menjadi lebih baik. Sementara itu, nilai IKK untuk komunikasi non verbal juga termasuk berkinerja SEDANG. Aspek ini juga menunjukan masih adanya kesenjangan angtara kepuasan dan harapan yang perlu diperkecil agar kualitas layanan dalam hal komunikasi pustakawan menjadi lebih baik. Dapat disimpulkan bahwa kepuasan pemustaka terhadap kemampuan bahasa pustakawan berpengaruh positif terhadap promosi dengan Word of Mouth (WOM). Terdapat lebih dari 20\% menyatakan akan menindaklanjuti kepuasaan dengan berbagai variasi aktivitas yang berkaitan dengan WOM. Berdasarkan diagram IPA, pihak pengelola akan memiliki urutan prioritas perbaikan terhadap kemampuan bahasa, verbal maupun non verbal, dari pustakawan. Pada diagram Importance and Performance Analisis (IPA) terlihat bahwa ada 5 atribut yang menjadi prioritas utama yang harus diperhatikan dalam hal komunikasi pustakawan UIN Bandung, 6 atribut yang harus dipertahankan kinerjanya, 6 atribut yang dianggap berlebihan yaitu dianggap oleh responden tidak penting tetapi kinerjanya bagus, 5 atribut yang tidak terlalu diprioritaskan, dan terdapat 2 atribut yang masuk ke dalam kategori antara dianggap tidak terlalu prioritas dan dianggap berlebihan. Pengembangan dari penelitian selanjutnya yang berkaitan dengan penelitian yang 
telah dilakukan adalah tinjauan terhadap hubungan antara Word of Mouth (WOM) dengan tingkat pemahaman institusional repository. Penelitian ini penting dilakukan mengingat tingkat pemanfaatan institusional repository yang masih belum optimal. WOM merupakan salah satu aspek yang dimungkinkan dapat meningkatkan pemanfaatan layanan ini, dan WOM merupakan pengaruh dari sisi faktor sosial, di samping faktor lain.

\section{DAFTAR PUSTAKA}

Andinouval R., M. (2018). Rancang bangun aplikasi analisis kepuasan pengguna layanan OPAC pada Perpustakaan Universitas Dr. Soetomo (Skripsi). Universitas Bisnis dan Informatika STIKOM Surabaya. Retrieved from http:/ / sir.stikom.edu/id/eprint/2782/ 1/14410100011-2018-COMPLETE.pdf

Berger, J. (2014). Word of mouth and interpersonal communication: A functional view. Journal of Consumer Psychology, 24(4), 586-607. https://doi.org/10.1016/j.jcps.2014.05. 002

Brendan E., \& Asogwa, B. U. (2014). Use of servQUAL in the evaluation of service quality of academic libraries in developing countries. Library Philosophy and Practice, 10(3), 1-25. Retrieved from https://digitalcommons.unl.edu/cgi/v iewcontent.cgi? article $=2947 \&$ context $=1 i$ bphilprac

Brown, T. J., Barry, T. E., Dacin, P. A., \& Gunst, R. F. (2005). Spreading the word: Investigating antecedents of consumers' positive word-of-mouth intentions and behaviors in a retailing context. Journal of the Academy of Marketing Science, 33(2), 123-138. Retrieved from https://scholar.google.co.id/scholar?hl $=\mathrm{id} \&$ as_sdt $=0 \% 2 \mathrm{C} 5 \& \mathrm{q}=$ Brown $\% 2 \mathrm{C}+\mathrm{T}$. $+\mathrm{J} . \% 2 \mathrm{C}+$ Barry $\% 2 \mathrm{C}+\mathrm{T} .+\mathrm{E} . \% 2 \mathrm{C}+$ Dacin $\%$ $2 \mathrm{C}+\mathrm{P} .+\mathrm{A} . \% 2 \mathrm{C}+\% 26+$ Gunst $\% 2 \mathrm{C}+\mathrm{R} .+\mathrm{F}$. $+\% 282005 \% 29 .+$ Spreading+the+word $\%$ $3 \mathrm{~A}+$ Investigating+antecedents+of + cons umers' + positive+word-ofmouth+intentions+and+behaviors+in+ a+retailing+context.+Journal+of + the $+\mathrm{A}$ cademy+of+Marketing+Science $\% 2 \mathrm{C}+3$ $3 \% 282 \% 29 \% 2 \mathrm{C}+123-$

138.+https \%3A \%2F\%2Fdoi.org\%2Fdoi \%3A10.1177\%2F0092070304268417\&btn $\mathrm{G}=$

Chen, Y., Wang, Q., \& Xie, J. (2011). Online social interactions: A natural experiment on word of mouth versus observational learning. Journal of Marketing Research, 48(2), 238-254. https://doi.org/10.1509/jmkr.48.2.238

Farida, F. I. (2011). Analisis kepuasan pelanggan terhadap kualitas pelayanan jasa Kereta Api Ekspres Pakuan Jabo: Studi Kasus Kereta Api Ekspres Pakuan (Skripsi). Institut Pertanian Bogor Bogor. Retrieved from https:// repository.ipb.ac.id/bitstream /handle/123456789/47741/H11fif.pdf

Fatmawati, E. (2012). Evaluasi kualitas layanan Perpustakaan FEB UNDIP berdasarkan harapan dan persepsi pemustaka dengan metode LibQUAL+TM. Berkala Ilmu Perpustakaan Dan Informasi, 8(1), 1-18. https://doi.org/10.22146/bip.7725

Fatmawati, E. (2013). Mata baru penelitian perpustakaan dari Seroqual ke Libqual+TM. Jakarta: Sagung Seto.

Indrawati, L. (2012). Meningkatkan kemampuan berbahasa lisan melalui metode bercerita pada kelompok B TK Tunas Karya Desa Wuluh Kecamatan Kesamben Kabupaten Jombang. Jurnal PAUD Teratai, 1(2), 1-20. Retrieved from 
https://jurnalmahasiswa.unesa.ac.id/i ndex.php/paudteratai/article/view/639/434

Kassim, N. A. (2009). Evaluating users' satisfaction on academic library performance. Malaysian Journal of Library \& Information Science, 14(2), 101$115 . \quad$ Retrieved from https://mjlis.um.edu.my/article/view /6960/4621

Li, F., \& Du, T. C. (2011). Who is talking? An ontology-based opinion leader identification framework forword-ofmouth marketing in online social blogs. Decision Support Systems, 51(1), 190-197. https://doi.org/10.1016/j.dss.2010.12.0 07

Martin, W. C., \& Lueg, J. E. (2013). Modeling word-of-mouth usage. Journal of Business Research, 66(7), 801808.

https://doi.org/10.1016/j.jbusres.2011. 06.004

Pebrianto, S. (2010). Pembangunan sistem informasi perpustakaan pada Perpustakaan Umum Kabupaten Pacitan. Journal Speed - Sentra Penelitian Engineering Dan Edukasi, 2(2), 43-47. Retrieved from https://ijns.org/journal/index.php/sp eed/article/view/1255/1243

Putri, N. R., \& Suhariadi, F. (2013). Hubungan antara kepuasan pelanggan dengan word of mouth pada pelanggan klinik kecantikan London Beauty
Centre. Jurnal Psikologi Industri Dan Organisasi, 2(3), 169-175. Retrieved from

http://journal.unair.ac.id/downloadfullpapers-jpioca23a678162full.pdf

Siyamto, Y. (2017). Kualitas pelayanan bank dengan menggunakan metode importance performance analysis (IPA) dan customer satisfaction index (CSI) terhadap kepuasan nasabah. Jurnal Ilmiah Ekonomi Islam, 3(1), 63-76. Retrieved from https://jurnal.stieaas.ac.id/index.php/jei/article/view/ $100 / 88$

Soeatminah. (1992). Perpustakaan, kepustakawanan dan pustakawan. Jakarta: Gramedia Pustaka Utama. Retrieved from

https://scholar.google.co.id/scholar?hl $=\mathrm{id} \&$ as_sdt $=0 \% 2 \mathrm{C} 5 \& \mathrm{q}=$ Soeatminah $+\%$ 281992\% 29+Perpustakaan\%2C+kepust akawanan+dan+pustakawan+\&btnG= Suwarno, W. (2009). Dasar-dasar ilmu perpustakaan: Sebuah pendekatan praktis. Yogyakarta: Ar-Ruzz Media.

Yanti, D. N. P. (2013). Kualitas komunikasi pelayanan customer service di PT Indosat, TBK Balikpapan. Ejournal Ilmu Komunikasi, 1(2), 39-54. Retrieved from https:// ejournal.ilkom.fisipunmul.ac.id/site/wpcontent/uploads/2013/04/ejournal Dwi Novel Putri Yanti (04-16-13-03-5835).pdf 


\section{DAFTAR TABEL}

Tabel 12

Responden yang merasa puas terhadap kemampuan berbahasa pustakawan

\begin{tabular}{|c|c|c|c|}
\hline Kode & Hal yang dinilai & Persen puas & Rata-rata nilai \\
\hline \multicolumn{4}{|c|}{ Aspek verbal } \\
\hline B1.1 & $\begin{array}{l}\text { Vokal yang diucapkan } \\
\text { pustakawan cukup jelas }\end{array}$ & $39.5 \%$ & 3.28 \\
\hline B1.2 & $\begin{array}{l}\text { Pustakawan menggunakan } \\
\text { pilihan kata yang baik dan tepat } \\
\text { dalam berkomunikasi }\end{array}$ & $39 \%$ & $3.26^{*}$ \\
\hline B1.3 & $\begin{array}{l}\text { Kalimat yang disampaikan jelas } \\
\text { dan mudah dipahami }\end{array}$ & $45 \%$ & $3.41^{*}$ \\
\hline B1.4 & $\begin{array}{l}\text { Struktur kalimat pustakawan } \\
\text { dalam berkomunikasi cukup } \\
\text { baik }\end{array}$ & $44 \%$ & 3.35 \\
\hline \multicolumn{4}{|c|}{ Aspek non verbal } \\
\hline B2.1 & $\begin{array}{l}\text { Gestur pustakawan membuat } \\
\text { nyaman pemustaka dan } \\
\text { mendukung komunikasi } \\
\text { verbalnya }\end{array}$ & $33.75 \%$ & $3.18^{*}$ \\
\hline B2.2 & $\begin{array}{l}\text { Posisi tubuh pustakawan saat } \\
\text { melakukan komunikasi dengan } \\
\text { pemustaka tepat dan nyaman } \\
\text { untuk berkomunikasi }\end{array}$ & $38.25 \%$ & 3.26 \\
\hline B2.3 & $\begin{array}{l}\text { Nada bicara pustakawan dalam } \\
\text { berkomunikasi dengan } \\
\text { pemustaka cukup memadai } \\
\text { untuk dapat didengar }\end{array}$ & $40 \%$ & 3.27 \\
\hline B2.4 & $\begin{array}{l}\text { Pustakawan menggunakan } \\
\text { intonasi yang tepat dalam } \\
\text { berkomunikasi }\end{array}$ & $41.5 \%$ & $3.30^{*}$ \\
\hline
\end{tabular}


Tabel 13

Indeks kepuasan konsumen terhadap komunikasi pustakawan

\begin{tabular}{llllll}
\hline Kode & Hal yang dinilai & $\begin{array}{l}\text { Rata-rata } \\
\text { kepuasan }\end{array}$ & $\begin{array}{l}\text { Rata-rata } \\
\text { harapan }\end{array}$ & WF & WS \\
\hline B1.1 & $\begin{array}{l}\text { Vokal yang diucapkan pustakawan cukup } \\
\text { jelas }\end{array}$ & 3,28 & 4,09 & 24,728 & 0,811 \\
B1.2 & $\begin{array}{l}\text { Pustakawan menggunakan pilihan kata } \\
\text { yang baik dan tepat dalam berkomunikasi }\end{array}$ & 3,26 & 4,16 & 25,151 & 0,82 \\
B1.3 & $\begin{array}{l}\text { Kalimat yang disampaikan jelas dan mudah } \\
\text { dipahami }\end{array}$ & 3,41 & 4,15 & 25,091 & 0,856 \\
B1.4 & $\begin{array}{l}\text { Struktur kalimat pustakawan dalam } \\
\text { berkomunikasi }\end{array}$ & 3,35 & 4,14 & 25,03 & 0,839 \\
Jumlah & & 13,3 & 16,54 & 100 & 3,325 \\
\hline
\end{tabular}


Tabel 14

Indeks kepuasan konsumen terhadap komunikasi pustakawan

\begin{tabular}{|c|c|c|c|c|c|}
\hline Kode & Hal yang dinilai & Rata- rata kepuasan & Rata-rata harapan & WF & WS \\
\hline B2.1 & $\begin{array}{l}\text { Gestur pustakawan } \\
\text { membuat nyaman } \\
\text { pemustaka dan } \\
\text { mendukung } \\
\text { komunikasi verbalnya }\end{array}$ & 3,18 & 4,07 & 24,667 & 0,784 \\
\hline B2.2 & $\begin{array}{l}\text { Posisi tubuh } \\
\text { pustakawan saat } \\
\text { melakukan } \\
\text { komunikasi dengan } \\
\text { pemustaka tepat dan } \\
\text { nyaman untuk } \\
\text { berkomunikasi }\end{array}$ & 3,26 & 4,12 & 24,970 & 0,814 \\
\hline B2.3 & $\begin{array}{l}\text { Nada bicara } \\
\text { pustakawan dalam } \\
\text { berkomunikasi } \\
\text { dengan pemustaka } \\
\text { cukup memadai } \\
\text { untuk dapat didengar }\end{array}$ & 3,27 & 4,14 & 25,091 & 0,820 \\
\hline B2.4 & $\begin{array}{l}\text { Pustakawan } \\
\text { menggunakan } \\
\text { intonasi yang tepat } \\
\text { dalam berkomunikasi }\end{array}$ & 3,3 & 4,17 & 25,273 & 0,834 \\
\hline Jumlah & & 13,010 & 16,500 & 100,000 & 3,253 \\
\hline
\end{tabular}


Tabel 15

Jumlah responden yang merasa setuju berdasarkan aspek WOM

\begin{tabular}{llll}
\hline Kode & Hal yang dinilai & Jumlah konsumen setuju & Persentase konsumen setuju \\
\hline C1 & $\begin{array}{l}\text { Apakah Anda sering berdiskusi } \\
\text { dengan teman/ pihak lain terkait } \\
\text { kualitas layanan Perpustakaan UIN }\end{array}$ & 95 & $23.75 \%$ \\
Bandung & & \\
C2 $\quad \begin{array}{l}\text { Apakah Anda memberikan informasi } \\
\text { tentang kualitas komunikasi } \\
\text { pustakawan kepada orang lain? }\end{array}$ & 89 & $22.25 \%$ \\
C3 $\quad \begin{array}{l}\text { Jika Anda mendapat informasi } \\
\text { tentang kualitas komunikasi } \\
\text { pustakawan akan mempengaruhi } \\
\text { keputusan Anda untuk berkunjung } \\
\text { atau tidak berkunjung ke }\end{array}$ & & $34 \%$ \\
$\begin{array}{l}\text { Perpustakaan } \\
\text { Apakah Anda akan mempromosikan } \\
\text { kualitas layanan, khususnya aspek } \\
\text { komunikasi Pustakawan kepada } \\
\text { orang lain, agar orang lain } \\
\text { berkunjung ke perpustakaan? }\end{array}$ & 150 & $37.5 \%$ \\
C4 & & \\
\hline
\end{tabular}


Tabel 16

Hubungan tingkat kepuasan responden berdasarkan aspek non verbal terhadap WOM

\begin{tabular}{lllll}
\hline Aspek non verbal & C1 & C2 & C3 & C4 \\
\hline $\begin{array}{l}\text { Gestur pustakawan membuat nyaman pemustaka dan mendukung } \\
\text { komunikasi verbalnya }\end{array}$ & 3.18 & 3.18 & 3.18 & 3.18 \\
$\begin{array}{l}\text { Posisi tubuh pustakawan saat melakukan komunikasi dengan } \\
\text { pemustaka tepat dan nyaman untuk berkomunikasi }\end{array}$ & 3.26 & 3.26 & 3.26 & 3.26 \\
$\begin{array}{l}\text { Nada bicara pustakawan dalam berkomunikasi dengan pemustaka } \\
\text { cukup memadai untuk dapat didengar }\end{array}$ & 3.27 & 3.27 & 3.27 & 3.27 \\
$\begin{array}{l}\text { Pustakawan menggunakan intonasi yang tepat dalam } \\
\text { berkomunikasi }\end{array}$ & 3.30 & 3.30 & 3.30 & 3.30 \\
\hline
\end{tabular}

